\title{
Using Classroom Response Technology To Create An Active Learning Environment In Marketing Classes
}

James A. Muncy, Valdosta State University, USA

Jacqueline K. Eastman, Georgia Southern University, USA

\begin{abstract}
Classroom response systems (CRS), also called student/audience response systems or clickers, have been used by business instructors, particularly in larger classes, to allow instructors to ask students questions in class and have their responses immediately tabulated and reported electronically. While clickers have typically been used to measure attendance, gauge comprehension and test students, we propose that classroom response systems can also be used to effectively create an active learning environment. Specifically we detail the use of classroom response systems to utilize active learning in large classes (i.e., more than 70 students) through describing five sample CRS exercises in Marketing courses: Sequential Elimination, Why Do You Think That?, Experiential Exercises, What Would You Do?, and Forced Choice. These exercises though, could be adapted for use in other business classes.
\end{abstract}

Keywords: Classroom Response Technology; Active Learning; Audience Response Systems; Clickers

\section{INTRODUCTION}

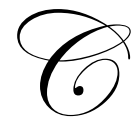

lassroom response systems (CRS), which are also variously labeled student/audience response systems or simply "clickers," allow instructors to ask questions of students in class and have their responses immediately tabulated and reported back to the instructor and/or the class electronically. Fies and Marshall (2006) conducted a meta-study of the CRS research and concluded that there is substantial agreement that CRS can yield positive classroom results. Recent research has shown that students are generally positive about the use of CRS in marketing classes (Eastman, Iyer, and Eastman 2011; FitzPatrick and Davey 2010; Lincoln 2008; Sprague and Dahl 2010). However, as pointed out by Lincoln (2008), "the ability of clickers to deliver these desirable outcomes is mostly a function of how they are used, not whether or not they are used" (p. 40). He went on to show that the proper use of CRS occurs when the objectives and pedagogy are driving the techniques and not vice versa.

When presented with student response technology, a tendency of instructors is to initially think in terms of attendance and in-class quizzes. Actually, it is probably not a good idea to use clickers by themselves to take attendance, especially in large classes. Responses from students do not ensure that the student was actually in class but rather that his or her clicker was there. It is possible for a student who is going to miss class to hand his or her clicker to a student who will attempt to, in a stealth way, answer questions for two students. Though not useful for attendance, clickers can be used to administer in-class quizzes. Lincoln (2008) found that around three-fourths of students like clicker quizzes because they get immediate feedback regarding their performance. Using clickers to assess students' retention and comprehension is effective because, if nothing else, it gives feedback to the professor who can then make adjustments on the fly or even for future semesters (Anderson and Noland 2010).

While the literature on CRS has focused most of its attention on using it for attendance and quiz purposes, receiving feedback about comprehension and retention is but one objective among many possible CRS objectives (see Lincoln 2008, p. 42-43). Another possible objective of using emerging classroom technology is to create an 
active learning environment in the classroom (Paladino 2008). Trees and Jackson (2007) conducted a clicker use study in large classes and found that students gained the most from clicker exercises that encourage student participation. The purpose of this article is to focus on the use and benefits of clicker technology to develop active learning in larger classes where creating an interactive and responsive environment is particularly difficult. Specifically, this article will first provide a brief literature review on the use of classroom response systems. Then this article will focus on the use of CRS to develop an active learning environment in the classroom, through providing five sample CRS techniques that have been used in large marketing classes, ranging in size from 75 to 270 students.

\section{LITERATURE REVIEW}

"It is important for professors to enhance student interest and input in a course, as this can have a significant effect on how satisfied a student is with a marketing course" (Eastman, Iyer, and Eastman, 2011, 139). The quality of interaction and communication between instructors and students is an important component of learning (Karakaya, Ainscough, and Chopoorian, 2001) and CRS is one tool that professors can use to achieve this (Terreri and Simmons, 2005; Eastman, 2007). Eastman, Iyer, and Eastman (2009) offer that interactive technology (CRS) can help instructors improve communication, attitudes, and interest in the classroom, while Eastman (2007) describes in detail how faculty can get started using interactive technology.

While instructors have typically used classroom response systems for attendance, gauging comprehension, and testing purposes (Eastman, 2007), the literature suggests that other purposes. Kurdziel (2005) describes how audience response systems can overcome the limitations of traditional lectures, engage students, and improve students' attitudes. Nelson and Hauck (2008) note that in large classes, it is almost impossible to do in-class activities without using interactive technology. Paladino (2008) discusses how educational technology can induce active learning, improve students' understanding of the material, and assist in forming competencies. Thus, CRS can increase students' active involvement in large classes (Taylor, 2007) and ensure students focus, participation, and interaction (Hoffman and Goodwin, 2006; Ueltschy, 2001). Lincoln (2008) describes specifically in large marketing classes, how CRS can increase student participation.

The literature supports the use of CRS for reasons beyond classroom management (i.e. attendance, measuring comprehension, testing) to also enhance active learning. With the use of CRS, instructors can effectively use active learning techniques, like those done in small classes, in much larger classrooms. How this paper contributes to the literature is by offering specific suggestions, in the next section, of CRS techniques to utilize active learning that have been used in Marketing classes and could be adapted for use in other business classes.

\section{FIVE SAMPLE CRS TECHNIQUES FOR MARKETING CLASSES}

This paper discusses our substantial experience in using clickers though discussing the use of them in classes that range in size from 75 students to 270. Clickers, in this case, are not used to elicit answers to quiz-type questions that focus primarily on information retention and/or comprehension. Rather, they are used to create an active, interactive classroom. We provide examples of some of the techniques that have proved useful for creating class participation, especially in larger classes. Though instructors using CRS techniques to create an active learning environment have many options (see Bruff 2008), we focus on five types of clicker exercises found to be particularly useful in large marketing classes, but could be adopted for use in other business classes.

\section{Sequential Elimination}

There are often several things that one must consider when developing successful marketing strategies, plans, etc. Thus, marketing classes are known for presenting students with lists. This creates a tendency for students to learn these lists with little thought to how they may apply to real world marketing situations. For example, introduction to marketing classes discuss environmental factors that affect marketing. A typical list would include economic, competitive, social, political, legal, and technological forces. Students in an introductory marketing class may look at this list without fully grasping that these factors really do affect how products are sold and distributed. 
Using a sequential elimination technique can encourage students to evaluate all the elements of a list as it relates to a specific marketing situation or challenge. Returning to the environmental factors affecting marketing, we have the students relate these factors to a specific industry (such as, the airline industry). Giving them the full list of six environmental factors, students get into groups of four to six and, as a group, decide which factor affects the airline industry the least. This creates greater focus on all the elements than asking them which one affects the airline industry the most. After the group discussion, everyone must click in so that students know what factor the class as a whole deems to relate the least to the airline industry. The one that receives the most votes is eliminated from the list and students must now decide which of the five remaining environmental factors affects the airline industry the least. This creates more discussion. This process is continued until only one is left and that would be the factor that the class as a whole believes to be the most important environmental factor. If class size and time allows, students can then be asked why they made the specific choices they did along the way. Because students are already actively discussing, they are much more likely to share their opinions with the class as a whole. We have found that this is much better for creating classroom discussion than simply asking how some concept relates in some marketing situation.

\section{Why Do You Think That?}

"Why do you think that?" is a technique that helps students think about some of the preconceived notions they hold. For example, students often fail the grasp that what works in one situation may not work in another situation. An example where clickers can be used to illustrate this point relates to test marketing a product. When test marketing is explained, students may tend to think that firms should always test market a new product before it is introduced. Here the "Why do you think that?" technique can be useful. This technique requires three steps. Students are initially asked to click in with a judgment. They are then asked to consider why they made that judgment. Then they are given the opportunity to reconsider their judgment.

Students can be given a situation involving the test marketing of a new product and asked if they think the firm introducing the product should test market it before it is commercialized. Usually a majority of students will say that they should. A follow-up slide will ask them why they chose the specific answer they did. The slide may include factors such as information gained about demand, information gained about marketing strategy, information lost to competitors, time lost in doing the test market, and the cost of the test market. Most students will say that their strongest consideration was the information gained about demand. This gives the instructor an opportunity to have students consider other factors that they should give strong consideration in making a decision.

When using clickers to create an active learning environment, it is very effective to ask the same question twice within the same exercise and have some discussion sandwiched in between (Ghosh and Renna 2009). So, after the full list has been discussed, students can be asked to reevaluate the original question. Many students may change their minds after considering the additional factors expounded upon during the discussion time. In the test marketing example, if the scenario presented to the students was one of a company that was playing on an element of surprise to gain a large customer base before competition could respond, students might realize the problem of giving away information to competitors that happens when products are test marketed. Perhaps students never considered the costs of running a successful test market and just assumed that, since products were being sold, profits were being made. Once they realize the expenses associated with a well-developed test market, they may conclude that the information gained is not worth the expense.

\section{Experiential Exercises}

Anything we can do to help students actually experience the concepts we are discussing, the more active they become in the learning process. At times, clickers can allow students to actually experience what is being taught. For example, when discussing the importance of perception in consumer behavior or advertising, instructors have often used the "Boring Figure" (Boring 1930) which is an ambiguous picture that can be perceived either as a young lady or an old woman. Some people are presented this picture and they see a young lady and others can see the same picture and see an old woman depending on how they interpret certain elements of it. What is relevant to marketing is that people can be primed to see either the young lady or the old woman. To help students understand this, the class is divided into two parts (Section 1 and Section 2). Section 1 stands up and faces the back wall while 
Section 2 is presented a modified copy of the picture that emphasizes the features of the young lady. Then Section 2 faces the back wall while Section 1 sees a modified copy of the picture that emphasizes the features of the old woman. Thus, before showing the actual ambiguous Boring Figure, students have been primed to see it as either a young lady or an old woman. Then the Boring Figure is showed to the whole class and asked to indicate whether this is a picture of a young lady or an old woman. The students also click in whether they were in Section 1 or Section 2. Then the two sections can be compared. The students are looking at the exact same figure and yet the students in Section 1 overwhelmingly see an old woman and Section 2 overwhelmingly see a young lady. We then go on to discuss how perception is not just the passive reception of a stimulus but rather an interaction with a stimulus based on predispositions.

This technique is particularly effective in teaching topics such as advertising where students can actually experience the advertisements. It makes use of what is sometimes called "demographic" slides where students are grouped based on their answers to questions and a comparison of responses can be made across groups. Students can be segmented based on a demographic or psychographic variable. An advertisement can then be shown which targets one segment and not the other. Students can then be asked to express their reaction to the advertisement and these answers can be compared between those who are in the target market and those who are not. For example, we have found that there is a fairly even split between people who want simplicity from their cell phones and those who like complexity with a lot of features. We utilize an advertisement that emphasizes simplicity (from the Windows "Really" campaign) and let students see their reactions to the commercial based on whether they want simplicity or complexity from their cell phones.

\section{What Would You Do?}

An obvious application of clickers in a marketing class is to give a scenario to students and ask them what they would do. This is usually more effective for creating an active learning environment if students are broken into groups to discuss the alternatives. For logistical reasons, it is usually easier to have students form their own groups. An effective way to make sure that all students are in a group of the appropriate size is to have a for-credit slide that asks them to click in once they are in a group and have the only alternatives be the acceptable number of students in a group (e.g., the question would be "I am in a group" and the answers would be "My group has 4 students..."). Also, if class wide discussion is desired, students can be told to appoint a spokesperson for their group and the question would become "I am in a group and we have a spokesperson."

Once students are in their groups, they are asked to select what they would do among the choices presented on the clicker slides. If discussion is to follow, they are told to have the spokesperson prepared to share with the class why a specific alternative was selected. Before the exercise is over, students will likely want to know what the instructor would do. Here is where the exercise can be very effective if well planned out. Students are attentive to what choice the instructor would make and his or her reason for making such a selection. If the proper scenario is used, the instructor can have either a real world example or empirical evidence to support his or her choice. So after getting students to commit to a specific course of action, the instructor can then say, "Well, there was some research that found that..." or "There was a company that faced that exact challenge and here is what it did..."

\section{Forced Choice}

A lively class discussion can develop when students are forced to choose between two mutually exclusive alternatives. For example, students often assume that, if you just have enough money to throw at a marketing problem, things will work out well. But money thrown on an ill-conceived strategy is just wasted. There is a clicker question that generates much lively debate and can be used to introduce the importance of learning foundational marketing concepts before just randomly throwing money at a marketing opportunity or problem. Students can be asked that, if forced to choose, would they rather have "great wisdom" or "\$100 million dollars."

There are three ways to ask this question depending on the desired level of interaction. The least interactive approach is to have students select their answers individually without discussion. To get greater interaction students discuss their choice in small groups but are allowed to select their own individual responses after group discussion. For the liveliest debate, students can be forced to agree as a group on one single answer. 


\section{RECEPTIVENESS TO CRS ACTIVE LEARNING}

For clicker exercises to have their maximum impact, students should see them as beneficial and enjoyable (Eastman, Iyer, and Eastman 2011; Sprague and Dahl 2010). Thus, these factors are important to consider when deciding on which clicker techniques to employ. In the spring semester 2011, clickers were used in two of the authors' classes, not to assess knowledge, but to engage students in active learning with exercises such as those presented in this paper. One class was an introduction to marketing class open almost exclusively to junior and senior business majors (enrolment $=78$ students) and the other was a sophomore level general elective open to all students (enrollment $=268$ students with $40 \%$ of the enrolled students majoring in business). At the end of the semester, students were allowed to anonymously provide comments regarding what they like best about the class and what needed improving. A total of 191 such comments were provided by students. Of these unaided responses, $13(7 \%)$ of them related to the use of the SRS in the class. Twelve of the thirteen comments were positive (92\%) and one was negative. The negative response was not related to the pedagogy of the clickers but rather the cost of buying it. Thus, as a whole it could be concluded that students have no significant concerns when using clickers in the manner presented here and at least some see great value to their use.

\section{CONCLUSION}

In this paper, we present five techniques (Sequential Elimination, Why Do You Think That?, Experiential Exercises, What Would You Do?, and Forced Choice) that can be incorporated into marketing classes, particularly larger sections which can create more of an active learning environment. A word of warning is in order, though, for those who have never used CRS in the classroom. Lincoln (2009) surveyed faculty about their perceptions of the use of clickers in the classroom. He found that, when compared to the beliefs of instructors who do not use clickers, those instructors who were using clickers believed that CRS were more useful but also more difficult to implement. Though technology has improved, it still requires a strong commitment by the instructor to make everything work properly. Even then, problems do occur. Thus, it is good to have a backup plan for those class periods when things do not work out as expected.

\section{AUTHOR INFORMATION}

James Muncy is a Professor of Marketing at Valdosta State University. He has published numerous articles that have appeared in the Journal of Marketing, Journal of Advertising, Journal of Advertising Research, Journal of Business Research, Journal of Marketing and Public Policy, Journal of Business Ethics, Journal of Marketing Education, Marketing Education Review, and other marketing related journals. Dr. Muncy spent five years as the Executive Director for the Association for Consumer Research. E-mail: muncyj@ valdosta.edu.

Jacqueline K. Eastman (Ph.D, Florida State University) is an Associate Professor of Marketing at Georgia Southern University. She has published in journals including Journal of Academy of Marketing Science, Journal of Business Research, Journal of Business Ethics, Journal of Advertising, Journal of Marketing Theory and Practice, Journal of Consumer Marketing, Journal of Marketing Education, Marketing Education Review, Journal of Education for Business, College Teaching Methods \& Styles Journal, American Journal of Business Education, and Contemporary Issues in Education Research among others. E-mail: jeastman@georgiasouthern.edu. Corresponding author.

\section{REFERENCES}

1. Anderson, W.A. and T.G. Noland (2010), "How Remote Response Devices Enable Student Learning: A Four-Year Analysis," American Journal of Business Education, 3 (August), 21-26.

2. Boring, E.G. (1930), "A New Ambiguous Figure," American Journal of Psychology, 42 (July), 444-445.

3. Bruff, D. (2009), Teaching With Classroom Response Systems, San Francisco: Jose-Bass.

4. Eastman, J.K. (2007), "Enhancing Classroom Communication With Interactive Technology: How Faculty Can Get Started," International College Teaching Methods \& Styles Journal, 3 (1), 31-38. 
5. Eastman, J.K., R. Iyer, and K.L. Eastman (2009), "Interactive Technology in the Classroom: An Exploratory Look At Its Use And Effectiveness," Contemporary Issues in Education Research, 2 (3), 31 38.

6. Eastman, J.K., R. Iyer, and K.L. Eastman, (2011), "Business Students' Perceptions, Attitudes, and Satisfaction With Interactive Technology: An Exploratory Study," Journal of Education for Business, 86 (September/October), 36-43.

7. Eastman, J.K., R. Iyer, and K.L. Eastman (2011), "Improving Undergraduate Student Satisfaction With The Consumer Behavior Course: Will Interactive Technology Help?", Marketing Education Review, 21 (2), 139-149.

8. $\quad$ Fies, C. and J. Marshall (2006), "Classroom Responses Systems: A Review of the Literature," Journal of Science Education and Technology, 15 (March), 101-109.

9. Ghosh, S. and F. Renna (2009), "Using Electronic Response Systems in Economics Classes," Journal of Economic Education, 40 (Fall), 354-465.

10. FitzPatrick, M. and J. Davey (2010), "Getting Personal With Marketing Research: A First Year Teaching Innovation. A Practical Report," International Journal of the First Year in Higher Education, 1 (July), 8490.

11. Kurdziel, J. (2005), "Using Large-Classroom Response Systems to Engage and Interact With Students," University of Michigan Center for Research on Learning and Teaching Provost Seminar 2005, University of Michigan Lecture Archives, Ann Arbor http://lecb.physics.lsa.umich.edu/CSIS/browser.php?ResourceID=3109/.

12. Lincoln, D.J. (2008), "Teaching With Clickers in the Large-Size Principle of Marketing Class," Marketing Education Review, 18 (Spring), 39-45.

13. (2009), "Student Response Systems Adoption and Use in Marketing Education: A Status Report," Marketing Education Review, 19 (Fall), 25-40.

14. Nelson, M.L. and R.V. Hauck (2008), "Clicking to Learn: A Case Study of Embedded Radio-Frequency Based Clickers In An Introductory Management Information Systems Course,” Journal of Information Systems Education, 19 (1), 55-64.

15. Paladino, A. (2008), "Creating and Interactive and Responsive Teaching Environment to Inspire Learning," Journal of Marketing Education, 30 (December), 185-188.

16. Sprague, E.W. and D.W. Dahl (2010), "Learning to Click: An Evaluation of the Personal Response System Clicker Technology in Introductory Marketing Courses," Journal of Marketing Education, 32 (April), 93 103.

17. Taylor, P.S. (2007), “Can Clickers Cure Crowded Classes?” Maclean's, 120 (26-27), 73.

18. Trees, A.R. and M.H. Jackson (2007), "The Learning Environment in Clicker Classrooms: Student Processes of Learning and Involvement in Large University-Level Courses Using Student Response Systems," Learning, Media and Technology, 32 (March), 21-40.

19. Ueltschy, L.C. (2001), "An Exploratory Study of Integrating Interactive Technology Into the Marketing Curriculum," Journal of Marketing Education, 23 (1), 63-72. 